\title{
IMPLEMENTATION OF THE BASIC CONCEPTS OF LEARNING THAT HAPPENED IN THE ERA OF THE COVID-19 PANDEMIC
}

\author{
Luthfia Nur Maulida ${ }^{1}$ \\ ${ }^{1}$ Pendidikan Guru Sekolah Dasar, Universitas Muhammadiyah Tangerang, Indonesia
}

\section{Article Info}

Article history:

Received: 04-02-2021

Revised: 04-08-2021

Published: 30-09-2021

\section{Keywords:}

Learners

Study method

Interview

ABSTRACT

There are so many students who feel uneasy in the implementation of learning during the COVID-19 pandemic, many of them complain that the continuity of learning at home is severely hampered because of the use of gadgets that can plunge them into playing online games. As we know, not only students among students at school, but many students also protest because they feel bored and do not enter the material taught by lecturers if explained through zoom meetings as is usually used in learning media, this is make various parties feel confused, is it actually the students who are lazy or the educators who can't master teaching skills? There must be a survey that proves accurately at each educational institution, so that both parties feel benefited and can change for the better. The author conducted research into several educational institutions to find out how many students feel they care about themselves and their education, especially education that will be the bridge for their future, if they don't understand from the bottom it will be difficult. The research method that the author will do is by sharing a link containing a Questionnaire which will later get answers from various parties, such as students who are still in Elementary School, Junior High School, High School and Students who are currently studying in Higher Education. , by not requiring them to mention the name of the school and the institution they are currently undergoing in order to maintain the good name of the school and related institutions. If this is not sufficient, then the author has a plan B, namely by interviewing several people around in order to obtain more accurate and honest results which are directly conveyed by the mouth of the informant.
\end{abstract}

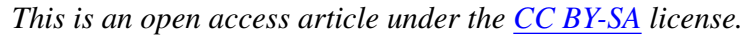

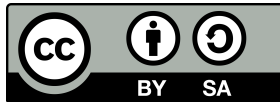

\section{Corresponding Author:}

Luthfia Nur Maulida,

Pendidikan Guru Sekolah Dasar, Universitas Muhammadiyah Tangerang, Indonesia

Email: luthfianurmaulida5@gmail.com

\section{INTRODUCTION}

The pandemic poses a special challenge for educators because in this situation learning is done online. Of course, this is a new challenge for educators. Education is the relationship between teachers and students to achieve educational goals that arise in the educational environment (Tulung, 2014). It has been proven by research that the author has done that both parties, aka between educators and students, find it very difficult to carry out learning and learning activities, ideas and evaluations of each school or agency are also needed in this case, for example SD A conducts learning evaluations every week so that knowing the extent of learning achievement, maximum or not, according to the learning plan or not, if $50 \%$ of the results are not obtained, then the strategy must be changed not the plan, the plan remains as the beginning of each educator's strategy 
must be changed in order to reach the peak as stated on initial planning. Students will be the determining factor so that they can influence everything needed to achieve learning goals (Hotimah, Ermiana, \& Rosyidah, 2021; Usriyah \& Prayogo, 2018).

Education can be interpreted as a process that uses methods to make them understand, know and behave when needed (Basilaia \& Kvavadze, 2020). According to the National Education System Law number 20 of 2003 Education is a conscious and planned effort to create an atmosphere of the education and learning process, therefore, students actively develop their potential to have spiritual strength, self-control, personality, noble intelligence and skills they need. need for themselves, the nation and society (Winarso \& Haqq, 2019). In this country, there has been a change in the curriculum that affects the development of education. Thus, education is the standard of teaching in schools. Success or failure in teaching depends on the teaching process carried out by the teacher (Juliansyah, 2021). Learning is the interaction between teachers that causes behavior change. In schools, teachers are one of the main factors in improving the quality of teaching. Therefore, the process must be designed in such a way that it can provide the desired learning outcomes. Not surprisingly, various philosophies and teaching methods have emerged in Indonesia that look new and modern, regardless of the source of their previous views, even long before that (Sutarti, 2017).

The distance learning system (PJJ), in its development, the distance learning system greatly benefits from the development of teaching technology, which can be filled with the need for a broad and broad education. Rapid advances in technology have led to the creation of flexible and intelligent distance learning models, as well as open access to education. Because of the teacher's role in the teaching and learning process in general, the teacher's role cannot be excluded, because learning is an interaction between teachers and students (Ainiyah \& Istiningsih, 2021). This is related to the existing theory, Although the COVID-19 outbreak has significantly affected the role of teachers in interacting with students, whether the existence of distance learning allows the role of teachers to interact properly. Therefore, this makes the author feel interested in conducting research with the title "Implementation of Basic Learning Concepts that occur in the Era of the Covid-19 Pandemic".

\section{RESEARCH METHOD}

The research method on this problem, steps are taken to adjust the title that the author has set, the research method used is the Qualitative Method, where this method focuses on deep observations, it is basically a scientific way to obtain data with certain goals and uses. Based on this, there are four keywords that need to be considered, namely: scientific method, data, purpose and usability. The scientific method means that research activities are based on scientific characteristics, namely rational, empirical, and systematic. Rational means that research activities are carried out in a way that makes sense so that it is affordable by human reasoning. Empirical means that the methods used can be observed by the human senses, so that other people can observe and know the methods used. Systematic means that the process used in the research uses certain logical steps (Sugiyono, 2016).

Because the current study uses qualitative research methods, the research will produce and manage descriptive data, such as interview transcripts, field notes, pictures, photos, video recordings and so on (Setyosari, 2013). This research is said to be qualitative because basically this research aims to examine or examine an object in a natural setting without any manipulation in it, and the expected results are not based on quantitative measures, but the meaning or aspect of the observed phenomenon. The approach in this research is a special study, where the researcher investigates carefully a program, event, activity, process or group of individuals. So, the researcher chose qualitatively by searching for information through interviews with one of the class teachers "SDN PAKUJAYA 1".

\section{RESULT AND DISCUSSION}

The basic concept of learning is an activity that poses in using very fundamental elements in the implementation of each type and level of education (Holt, Beer, Kronenberger, Pisoni, \& Lalonde, 2012). This is in accordance with the results of the study that the research method used and some of the strategies that the author carried out got positive results because they felt it was suitable in terms of analyzing the results at the end of the study, because the authors knew that the success or failure of achieving educational goals was very dependent on the learning process that students underwent. either when he is at school or at home or in his own family environment. For this reason, a correct understanding of the basic concepts of learning with all its aspects and forms and manifestations is absolutely needed by teachers. Some of the results that have 
been obtained are that learning in the Pandemic Era like this occurs. There is an error or incompleteness in their perception of the learning process and matters related to it may result in poor quality learning outcomes achieved by students (Arifmiboy, 2019).

There are some people who think that the basic concept of learning is merely memorizing or collecting facts that exist in the form of information or material in the lesson. So people who think like that will usually immediately feel proud when their children can verbally mention back most of the information in the textbook or taught by the teacher. In addition, there are also some people who view learning as an exercise. as seen in reading and writing exercises. This kind of perception usually makes them feel quite satisfied if their children have been able to demonstrate certain physical skills even without knowledge of the meaning and nature and purpose of these skills (Taher, Basar, Abdelrahman, \& Beler-Baykal, 2018).

Definition of Learning are:

- Relatively permanent changes occur in the behavioral potential of an experience.

- Chance (1986): "Learning is defined as a relatively long-lasting change in behavior resulting from experience"

- Domjan \& Bukhard "Learning is a long-lasting change in the mechanism of behavior or that results from experience with environmental events"

- Hergenhahn \& Bolson (1997): "Learning is a relatively permanent change in behavior or in behavioral potentiality resulting from experience and cannot be attributed to temporary bodily conditions such as bodily conditions caused by disease, fatigue or drugs. (Magdalena, Ina. 2020. Educational psychology teaching materials).

Meanwhile, according to Howard L. Kingskey said that "Learning is the process by which behavior (in the broader sense) is originated or changed through practice or training". exercise) (Djamarah, 2011). Based on some of the definitions of learning above, it can be concluded that learning is a process of changing behavior obtained from previous experience through practice or practice. From the various definitions of learning that have been put forward by these experts, it can be concluded that learning is essentially a process of assigning something to be learned. The assignment can be in the form of understanding (understanding), feeling, and being able to do something.

Starting from the various thoughts of these experts, learning can be defined as an activity or a conscious effort to improve the quality of ability or behavior by mastering a number of knowledge, skills, values and attitudes. Formal learning is an effort to complete an educational program at a school or college with the guidance of a teacher or lecturer. Meanwhile, self-taught learning or also called self-study or independent learning is learning that is carried out outside the educational program at school or college, but through one's own efforts. As a result of this learning, it can cover several aspects, including aspects of knowledge, skills, attitudes and values (Nessipbayeva, 2019).

The learning process, Process is a word that comes from the Latin "processus" which means "walking forward". According to Chaplin (1927), the process is any change in any object or organism, particularly a behavioral or psychological change. Meanwhile, according to Bain, et al. (2011) process means special ways or steps that cause some changes to achieve certain results. From these two opinions, we can conclude that the process can be defined as the stages of changes in cognitive, affective, and psychomotor behavior that occur in children. The change is positive in the sense that it is oriented in a more advanced direction than the previous state.

Phases in the learning process, because learning is a process activity, there are gradual changes in it. These stages arise through phases that are interconnected sequentially and functionally.

According to Jerome S. Brunner, in the learning process, children go through three phases, namely:

1. Information phase (material acceptance stage). A child is receiving material, among which there is material that is new and independent, there is also a function that adds, refines, and deepens the knowledge that was previously owned.

2. Transformation phase (change of material in memory). In this phase, the information that has been obtained in the previous phase is analyzed or changed or transformed into an abstract or conceptual form so that later it can be used for broader things.

3. Evaluation phase (assessment of material mastery). In the evaluation phase, the child assesses himself to what extent knowledge (transformed information) can be used to solve the problems at hand.

According to Wittig (1981) in his book Psychology of learning, every learning process always takes place in three phases or stages, namely: 
1. Acquisition (stage of acquiring or receiving information). At this stage, children begin to receive information as a stimulus and respond to it, giving rise to new understanding and behavior. The acquisition process in learning is the most basic stage. Failure in this stage results in failure in subsequent stages.

2. Storage (stage of receiving information). At this stage, the child will automatically experience the process of storing the new understanding and behavior that he acquired during the acquisition process.

3. Retrieval (stage of retrieving information). The retrieval stage is basically an effort or mental event in expressing and reproducing what is stored in memory in the form of information, symbols, understanding, and certain behaviors as a response or stimulus being faced.

A good way of learning, every student who wants to succeed in learning will definitely try so that his goals can be achieved. Various efforts can be made to obtain maximum results. Efforts to obtain maximum results are essentially learning in a good, appropriate, appropriate and effective way. However, everyone's learning model can be different because a person's experience of success in his studies is not always the same.

\section{CONCLUSION}

The results of the research that the author did this time, it was concluded that the obstacles, solutions and expectations in learning using the online system became an interesting topic during the Covid-19 pandemic. which is completely limited due to the COVID-19 pandemic but can still do online learning. The only obstacle is that parents have to add more time to accompany their children. Meanwhile, in terms of teachers, teachers become technology literate and are required to learn many things, especially -based learning.

\section{REFERENCES}

Ainiyah, N., \& Istiningsih, S. (2021). PENGARUH PENGGUNAAN METODE EVERYONE IS A TEACHER HERE THE EFFECT OF USING EVERYONE IS A TEACHER HERE METHOD ON. Renjana Pendidikan Dasar, 1(1).

Arifmiboy. (2019). Tadaluring Microteaching: An Effective Learning Model to Develop Basic Teaching Skills. Jurnal Pendidikan Teknologi dan Kejuruan, 25(1), 141-151. doi:10.21831/jptk.v25i1.23157

Bain, S., Fedynich, L., \& Knight, M. (2011). The successful graduate student: a review of the factors for success. Journal of Academic and Business Ethics, 12(4), 156-167.

Basilaia, G., \& Kvavadze, D. (2020). Transition to Online Education in Schools during a SARS-CoV-2 Coronavirus Transition to Online Education in Schools during a SARS-CoV-2 Coronavirus (COVID-19) Pandemic in Georgia. Pedagogical Research, 5(4), 1-9. doi:10.29333/pr/7937

Djamarah, S. B. (2011). Psikologi Belajar. Jakarta: PT. Rineka Cipta.

Holt, R. F., Beer, J., Kronenberger, W. G., Pisoni, D. B., \& Lalonde, K. (2012). Cochlear Implant Users' Speech and Language Outcomes: Some Preliminary Findings. Journal of Speech Language and Hearing Research, 55(June), 848-864. doi:10.1044/1092-4388(2011/11-0143)vocabulary

Hotimah, H., Ermiana, I., \& Rosyidah, A. N. K. (2021). Pengembangan Multimedia Interaktif Berbasis Macromedia Flash Untuk Meningkatkan Kemampuan Komunikasi Matematis. Progres Pendidikan, 2(1), 7-12. doi:10.29303/prospek.v2i1.57

Juliansyah, A. (2021). HUBUNGAN KOMUNIKASI DALAM KELUARGA TERHADAP MOTIVASI BELAJAR PESERTA DIDIK KELAS IV SDN GUGUS 02 KECAMATAN ALAS COMMUNICATION RELATIONSHIP WITH THE FAMILY TO THE LEARNING MOTIVATION OF CLASS IV STUDENTS OF SDN GUGUS 02 KECAMATAN ALAS IN ACADEMIC YEAR 2019. Renjana Pendiidkan Dasar, 1(1), 23-29.

Nessipbayeva, O. (2019). The Competencies of the Modern Teacher. Pre-Service and In-Service Teacher Training, 20(3), 802-819.

Setyosari, P. (2013). Metode Penelitian Pendidikan \& Pengembangan. Bandung: Prenadamedia group.

Sugiyono. (2016). Metode penelitian kuantitatif kualitatif dan R\&D. Bandung: Alfa Beta.

Sutarti, T. (2017). Efforts to Increase Students Reading Interest on Educational Reference Through Classical Guidance and Counseling Experiential Learning Model. JETL (Journal Of Education, Teaching and Learning), 2(1), 118. doi:10.26737/jetl.v2i1.152

Taher, M. N., Basar, A., Abdelrahman, A. M., \& Beler-Baykal, B. (2018). Yellow Water to Aid Food Security-Perceptions/Acceptance of Consumers toward Urine Based Fertilizer. Proceedings, 2(11), 606. doi:10.3390/proceedings 2110606 
Tulung, J. M. (2014). Evaluasi Program Pendidikan Dan Pelatihan Kepemimpinan Tingkat IV di Balai Diklat Keagamaan Manado. Jurnal Acta Diurna, 3(3).

Usriyah, L., \& Prayogo, M. S. (2018). Problematika Implementasi Pembelajaran Tematik Integratif di Lembaga Pendidikan Dasar Islam: Studi Kasus di Madrasah Ibtidaiyah Negeri (MIN) Garahan Jember Jawa Timur. TADRIS: Jurnal Pendidikan Islam, 13(2). doi:10.19105/tjpi.v13i2.1678

Winarso, W., \& Haqq, A. A. (2019). Psichological disposition of student; Mathematics anxiety vesus happines learning on the level education. International Journal of Trends in Mathematics Education Research, 2(1), 19. doi:10.33122/ijtmer.v2i1.32 